\title{
Primary resistance to cetuximab therapy in EGFR FISH-positive colorectal cancer patients
}

\author{
F Cappuzzo*,', M Varella-Garcia ${ }^{2}$, G Finocchiaro',2, M Skokan'2, S Gajapathy ${ }^{2}$, C Carnaghi', L Rimassa', E Rossi ${ }^{3}$, \\ C Ligorio ',4, L Di Tommaso', AJ Holmes ${ }^{5}$, L Toschi', G Tallini ${ }^{4}$, A Destro', M Roncalli', A Santoro' and \\ PA Jänne ${ }^{5}$ \\ 'Department of Medical Oncology, Istituto Clinico Humanitas IRCCS, Milan University, Rozzano, Italy; ${ }^{2}$ Department of Medicine/Medical Oncology, \\ University of Colorado Cancer Center, Aurora, CO, USA; ${ }^{3}$ CINECA-Interuniversity Consortium, Bologna, Italy; ${ }^{4}$ Pathology Unit, Bologna University, Bellaria \\ Hospital, Bologna, Italy; ${ }^{5}$ Department of Medical Oncology, Dana-Farber Cancer Institute, Boston, MA, USA; ${ }^{6}$ Pathology Unit, Istituto Clinico Humanitas \\ IRCCS, Milan University, Rozzano, Italy
}

The impact of KRAS mutations on cetuximab sensitivity in epidermal growth factor receptor fluorescence in situ hybridisation-positive $(E G F R$ FISH + ) metastatic colorectal cancer patients (mCRC) has not been previously investigated. In the present study, we analysed KRAS, BRAF, PIJKCA, MET, and IGFIR in $85 \mathrm{mCRC}$ treated with cetuximab-based therapy in whom EGFR status was known. KRAS mutations (52.5\%) negatively affected response only in EGFR FISH + patients. EGFR FISH + IKRAS mutated had a significantly lower response rate $(P=0.04)$ than EGFR FISH + IKRAS wild type patients. Four EGFR FISH + patients with KRAS mutations responded to cetuximab therapy. BRAF was mutated in 5.0\% of patients and none responded to the therapy. PI3KCA mutations (I7.7\%) were not associated to cetuximab sensitivity. Patients overexpressing IGFIR (74.3\%) had significantly longer survival than patients with low IGFIR expression $(P=0.006)$, with no difference in response rate. IGFIR gene amplification was not detected, and only two (2.6\%) patients, both responders, had MET gene amplification. In conclusion, KRAS mutations are associated with cetuximab failure in EGFR $\mathrm{FISH}+\mathrm{mCRC}$, even if it does not preclude response. The rarity of MET and IGFIR gene amplification suggests a marginal role in primary resistance. The potential prognostic implication of IGFIR expression merits further evaluation.

British Journal of Cancer (2008) 99, 83-89. doi: I0.1038/sj.bjc.6604439 www.bjcancer.com

Published online 24 June 2008

(c) 2008 Cancer Research UK

Keywords: cetuximab; EGFR; KRAS; BRAF; MET; IGFIR

With about 400000 cases each year, colorectal cancer (CRC) is one of the most common human malignancies and one of the leading causes of cancer-related death in the western world (Jemal et al, 2007). During the last decade, median duration of survival among patients with metastatic CRC (mCRC) has increased from 12 to 21 months, mainly because of the introduction of new cytotoxic agents such as oxaliplatin and irinotecan (De Gramont et al, 2000; Douillard et al, 2000).

Improvements in the knowledge of cancer biology has led to the development of agents that specifically inhibit tumour growth. The epidermal growth factor receptor (EGFR) is often upregulated in CRC, and monoclonal antibodies represent one of the most important options to inhibit such a target. Cetuximab (Erbitux, Merck, Lyon, France), a monoclonal antibody interfering with the extracellular domain of EGFR, has proven to be active in EGFR expressing CRC in whom other treatments have failed (Jonker et al, 2007). However, only a small proportion of patients $(<20 \%)$ achieve an objective response, and tumour shrinkage is not confined to patients with high level of EGFR protein expression determined by immunohistochemistry (IHC, Chung et al, 2005).

\footnotetext{
*Correspondence: Dr F Cappuzzo, Department of Medical Oncology, Istituto Clinico Humanitas IRCCS, via Manzoni 56, Milan University, Rozzano-20089, Italy; E-mail: federico.cappuzzo@humanitas.it Received 3I March 2008; accepted 21 April 2008; published online 24 June 2008
}

Recently, several studies provided relevant insights on mechanisms underlying cetuximab sensitivity. Retrospective analyses showed that tumour regression is more frequently observed among patients with increased EGFR gene copy number (Moroni et al, 2005; Sartore-Bianchi et al, 2007; Cappuzzo et al, 2008), while lack of response and short survival was observed in individuals harbouring a KRAS mutation (Lièvre et al, 2006, 2008; Di Fiore et al, 2007; Khambata-Ford et al, 2007; Amado et al, 2008; De Roock et al, 2008). Nevertheless, the incidence of KRAS mutations in CRC cannot account for all resistant cases (Bamford et al, 2004), and a consistent proportion of patients with increased EGFR gene copy number does not respond to the therapy (SartoreBianchi et al, 2007; Cappuzzo et al, 2008). For instance, in our previous experience (Cappuzzo et al, 2008), disease progression was observed in $39.5 \%$ of patients with EGFR gene gain detected by fluorescence in situ hybridisation (EGFR FISH + ).

Several preclinical findings suggest that $M E T$, the hepatocyte growth factor receptor, could interfere with anti-EGFR strategies. $M E T$ is a tyrosine kinase receptor (RTK) involved in cellular proliferation and apoptosis (Jiang et al, 1999). Activation of MET may lead to the activation of pathways downstream of Ras (Graziani et al, 1991; Halaban et al, 1992; Rodriguez-Viciana et al, 1994), such as the Raf/MEK/mitogen-activated protein kinase (MAPK) and the phosphatidylinositol 3-kinase (PI3K)/protein kinase $\mathrm{B}$ pathway (PKB). In addition, $M E T$ is able to directly activate $\mathrm{PI} 3 \mathrm{~K} / \mathrm{PKB}$ pathway in a Ras independent manner 
(Ponzetto et al, 1993). Concomitant RTK upregulation including $M E T$ is common in human carcinomas with high frequency of KRAS mutations, including colorectal cancer (Long et al, 2003). Moreover, studies in lung cancer have shown that MET gene amplification is responsible for acquired resistance to EGFRtyrosine kinase inhibitors (Engelman et al, 2007).

The insulin-like growth factor receptor 1 (IGF1R) is a tetrameric transmembrane RTK implicated in promoting oncogenic transformation, growth, and survival of cancer cells (Baserga et al, 1997; Blakesley et al, 1997; Dufourny et al, 1997; Khandwala et al, 2000). IGF1R activation triggers a cascade of reactions involving the Raf/ MEK/MAPK and the PI3K/PKB pathways (LeRoith et al, 1995; Jones and Clemmons, 1995). Data on glioblastoma cell lines suggested that IGF1R mediates resistance to anti-EGFR therapy through continued activation of the PI3K-AKT pathway (Chakravarti et al, 2002). IGF1R results in upregulation in the majority of CRC, most likely contributing to the aggressive growth characteristics of these tumours and poor prognosis (Hakam et al, 1999; Weber et al, 2002).

The impact of KRAS mutations on cetuximab sensitivity in EGFR FISH + patients has not been previously investigated. Moreover, no clinical data exist on whether MET or IGF1R gene gain could interfere with cetuximab sensitivity. On the basis of these premises, we decided to conduct a study exploring the impact of different biomarkers, including KRAS, MET and IGF1R, on primary resistance to cetuximab therapy in metastatic, chemorefractory, and CRC with known EGFR FISH status.

\section{MATERIALS AND METHODS}

\section{Patient selection}

The present study was conducted in a cohort of 85 chemorefractory, mCRC patients exposed to cetuximab-based therapy and previously evaluated for EGFR by FISH (Cappuzzo et al, 2008). Briefly, in our previous experience, patients were selected based on two main criteria: presence of at least one measurable lesion and availability of tumour tissue. No other clinical or biological criterion was used for patient selection. Cetuximab was given to each patient at the initial dose of $400 \mathrm{mg}$ per square meter, followed by weekly infusion of $250 \mathrm{mg}$ per square meter. In all patients, disease assessment was performed every 2 months, with a confirmatory evaluation no less than 4 weeks after the response assessment, according to the RECIST criteria (Therasse et al, 2000). The whole study population included 85 patients all pretreated with chemotherapy, including irinotecan (83.5\%) and/ or oxaliplatin $(84.7 \%)$. The majority of patients were male $(63.5 \%)$ with a performance status of $0-1(96.5 \%)$, and with a median age of 63.2 years, with a primitive tumour in colon $(76.5 \%)$ or rectum $(23.5 \%)$. EGFR was assessed by FISH in tumour samples from primary tumour (43 cases), from metastasis (20 cases) or both primary tumour and corresponding metastasis (22 cases). A mean $\geqslant 2.92$ EGFR gene copy number qualified the sample as EGFR FISH +. Among the 85 evaluable patients, 43 (50.6\%) were EGFR FISH + and $42(49.4 \%)$ were EGFR FISH-. Cetuximab therapy produced a significantly higher response rate (RR, 32.5 vs $2.3 \%$, $P<0.0001$ ) and a significantly longer time to progression (TTP, 6.6 vs 3.5 months, $P=0.02$ ) in EGFR FISH + than in EGFR FISHpatients. The study was approved by the local Ethics Committee and was conducted in accordance with ethical principles stated in the most recent version of the Declaration of Helsinki.

\section{Tissue preparation and IHC analysis}

Sections from paraffin-embedded tissue blocks containing representative malignant cells obtained at time of diagnosis were used for this analysis. Sections were stained with antibodies against IGF1R (Novus Biologicals, Littleton, CO, USA) according to the manufacturer's recommended protocols. Briefly, $4 \mu \mathrm{m}$-thick tissue sections were placed on glass slides and deparaffinised. The tissue sections were incubated in $1 \mathrm{mM}$ EDTA ( $\mathrm{pH} 8$ ) for $40 \mathrm{~min}$ at $98^{\circ} \mathrm{C}$ to unmask the antigens. The sections were then incubated with IGF1R mouse antibody (1:50 diluted in phosphate buffer).

Immunohistochemical staining was performed at the Pathology Department of Istituto Clinico Humanitas, Italy and slides were interpreted independently by two pathologists (CL and LDT) who were blinded to all patient information. As previously described for IGF1R in lung cancer (Cappuzzo et al, 2006), a semiquantitative approach was used to generate a score for each tissue core. The percentage of stained cells $(0-100 \%)$ was multiplied by the dominant intensity pattern of staining, considering one as negative or trace, two as weak, three as moderate and four as strong. Therefore, the overall score ranged from 0 to 400 .

\section{FISH analyses}

Blank tumour sections were submitted to dual-colour FISH assays using in-house developed IGF1R/CEP15 and MET/CEN7 probe cocktails on separate slides for each patient. The assays were performed according to standard laboratory protocol. Initially the slides were incubated for $2 \mathrm{~h}$ - overnight at $65^{\circ} \mathrm{C}$, deparaffinised in Citro-Solv (Fisher) and washed in $100 \%$ ethanol for $5 \mathrm{~min}$. The slides were incubated in $2 \mathrm{XSSC}$ at $75^{\circ} \mathrm{C}$ for $6-22 \mathrm{~min}$ and digested in $0.25 \mathrm{mg} \mathrm{ml}^{-1}$ Proteinase $\mathrm{K} / 2 \mathrm{XSSC}$ at $45^{\circ} \mathrm{C}$ for $6-25 \mathrm{~min}$. Then, the slides were washed in 2XSSC for $5 \mathrm{~min}$ and dehydrated in ethanol. Probes were applied to the selected hybridisation areas (150-300 ng of labelled DNA for each specimen), which were covered with glass coverslips and sealed with rubber cement. DNA denaturation was performed for $15 \mathrm{~min}$ at $80^{\circ} \mathrm{C}$ and the slides were incubated at $37^{\circ} \mathrm{C}$ for $40-48 \mathrm{~h}$.

Posthybridisation washes were performed with $2 \mathrm{XSSC} / 0.3 \% \mathrm{NP}$ 40 at $72{ }^{\circ} \mathrm{C}$ for $2 \mathrm{~min}$. Then, the slides were washed in $2 \mathrm{XSSC}$ for $1 \mathrm{~min}$ and dehydrated in ethanol. Chromatin was counterstained with DAPI $\left(0.3 \mu \mathrm{g} \mathrm{m}^{-1}\right.$ in Vectashield, Vector Laboratories). Analysis was performed on epifluorescence microscopes using single interference filter sets for green (FITC), red (Texas red), aqua (Aqua) and blue (DAPI) as well as dual (red/green) and triple (blue, red, green) band pass filters. Each specimen was evaluated in eight different tumour foci with 10 cells analysed in each area (total of 80 cells per specimen).

\section{Mutation analyses}

Additional biomarkers analysed in the present study included $K R A S, B R A F$, PI3KCA, and AKT. Mutations in KRAS (exons 1 and 2), BRAF (exons 11 and 15), PIK3CA (exons 9 and 20) and $A K T$ (exon 3) were examined using a previously published DNA endonuclease (Surveyor ${ }^{\mathrm{TM}}$ ) based method (Jänne et al, 2006). Exonspecific PCR amplification was carried out for each of the indicated genes, the resulting DNA products were subjected to Surveyor ${ }^{\mathrm{TM}}$ digestion and analysed using the Transgenomic WAVE HS system as previously described (Jänne et al, 2006). All mutations were independently confirmed. PCR primers and conditions are available upon request.

\section{Statistical analyses}

Statistical analyses were conducted using biomarker results obtained on primary tumours, except in 20 cases where only tissue from metastasis was available. The primary end point of the study was the identification of biomarkers potentially associated with progression of disease under cetuximab therapy. Analysis of ROC (receiver operating characteristic) curve was carried out with the aim of determining a cutoff point for $M E T$ and $I G F 1 R$ 
expression or gene copy numbers as a continuous variable (Cai and Moskowitz, 2004). Sensitivity and specificity were expressed in terms of percentage and the value for which sensitivity and sensibility were the highest has been chosen as the best cutoff point. Secondary end points were association with TTP and overall survival (OS). TTP was calculated from the time of first cetuximab infusion to time of disease progression or last disease assessment. OS was calculated from the time of first cetuximab infusion to patient death or last contact.

Differences in response rate were compared by Fisher's exact test or $\chi^{2}$ test. TTP, OS and the $95 \%$ confidence intervals were evaluated by survival analysis using Kaplan-Meier method (Kaplan and Meier, 1985). TTP and OS for the groups with negative and positive biomarker were compared using the log-rank test. Statistical significance was set at $<0.05$ for each analysis. All statistical analyses were performed using SPSS version 11.5.1 (SPSS Italia srl, Bologna, Italy).

\section{RESULTS}

\section{MET analysis}

MET FISH analysis was successfully performed in 76 patients (Table 1). Receiver operating characteristic curve analysis was performed to identify the MET copy number cutoff that better discriminates a resistant population but no association was found with drug sensitivity. MET increased gene copy numbers (MET FISH + ) were then defined as mean $\geqslant 5$ per cell, which was observed in seven patients $(9.2 \%)$, including two $(2.6 \%)$ with gene amplification and five $(6.6 \%)$ with high polysomy. Interestingly, all MET FISH + cases were also EGFR FISH +, and such association was statistically significant $(P=0.006)$. Nevertheless, $M E T$ FISH + status was not associated with resistance to cetuximab therapy, and no difference in progressive disease rate was observed between EGFR FISH + IMET FISH + and EGFR FISH + IMET FISH $-(42.8$ vs $37.5 \%, P=0.7)$.

\section{IGF1R analyses}

IGF1R was successfully analysed by FISH in 77 cases and by IHC in 70 cases. In the gene copy number evaluation, ROC analysis did not identify a cutoff discriminating sensitive $v s$ resistant patient populations and no $\mathrm{mCRC}$ had mean $>5$ copies per cell to be called IGF1R FISH + . The mean IGF1R copy number ranged from 1.43 to 4.88 among the investigated mCRC. IGF1R gene copy number was not associated with IGF1R IHC expression (Pearson correlation coefficient $0.034, P=0.7)$. As shown in Figure $1 \mathrm{~A}$, the
ROC analysis found an IGF1R IHC value of 95 associated with a sensitivity of $90 \%$ (CI: $71.4-100$ ) and a specificity of $28.3 \%$ (CI: $16.9-39.7)$. Using this cutoff, 18 patients $(25.7 \%)$ resulted negative and $52(74.3 \%)$ positive (Table 2$)$. Although response rate and TTP were not significantly different in the two groups, IGF1R IHC + patients had a significantly longer survival than IGF1R IHC- (16.1 $v s 6.7$ months, $P=0.006$ ), as shown in Figure 1B. No difference in progressive disease rate was observed in EGFR FISH + /IGF1R $\mathrm{IHC}+(\mathrm{N}=26)$ vs EGFR FISH +/IGF1R IHC $-(\mathrm{N}=9 ; 42.3$ vs $44.4 \%, P=0.9)$.

\section{Mutation analyses}

KRAS analysis was successfully performed in 80 cases, and 42 patients $(52.5 \%)$. harboured a mutation, with G13D as the most frequent mutation type (eight cases, $10.0 \%$ ). Such mutations were not associated with clinical or biological characteristics and occurred in 22 EGFR FISH + patients (53.7\%). As illustrated in Table 3, response rate significantly favoured patients with KRAS wildtype $(P=0.048)$, as well as TTP and OS, although these differences were not statistically significant $(P=0.2$ and 0.3 , respectively).

$B R A F$ was analysed in 79 cases, and only four patients $(5.1 \%)$ harboured a mutation (V599E). BRAF and KRAS mutations were mutually exclusive. Owing to the low number of patients carrying a $B R A F$ mutation the statistical power was not enough to detect difference in outcome. Nevertheless, none of the four BRAFmutated patients responded to cetuximab therapy, and TTP and
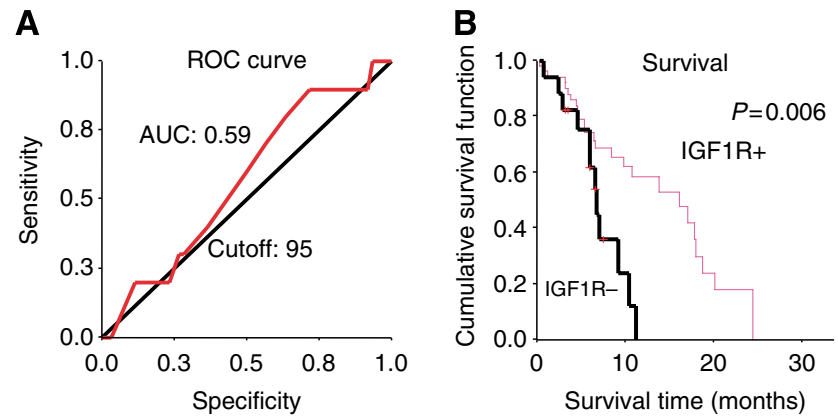

Figure I (A) ROC analysis identified an IGFIR value of 95 associated with a sensitivity of $90 \%(\mathrm{Cl}: 71.4-100)$ and a specificity of $28.3 \%(\mathrm{Cl}$ : | 6.9-39.7). (B) Patients IGFIR positive (score $\geqslant 95$ ) had a median survival of 16.1 months vs 6.7 months in IGFIR negative patients $(P=0.006)$.

Table I Association of MET gene copy number with outcome to cetuximab therapy and patient biomarker status

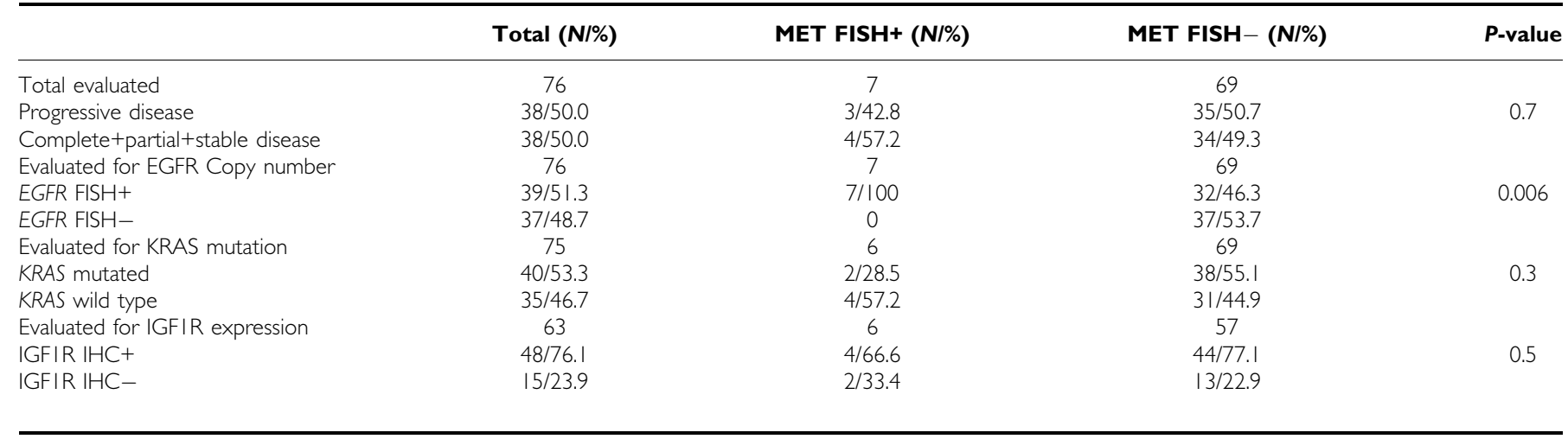

A mean $\geqslant 5$ MET gene copy number qualified the sample as MET FISH positive. A mean $\geqslant 2.92$ EGFR gene copy number qualified the sample as EGFR FISH positive. Among the 76 patients evaluated for MET, all were evaluated for EGFR FISH, 75 were evaluated for presence of KRAS mutations, and 63 for IGFIR expression. 
Table 2 Association of IGFIR expression with patient biomarker status and outcome to cetuximab therapy

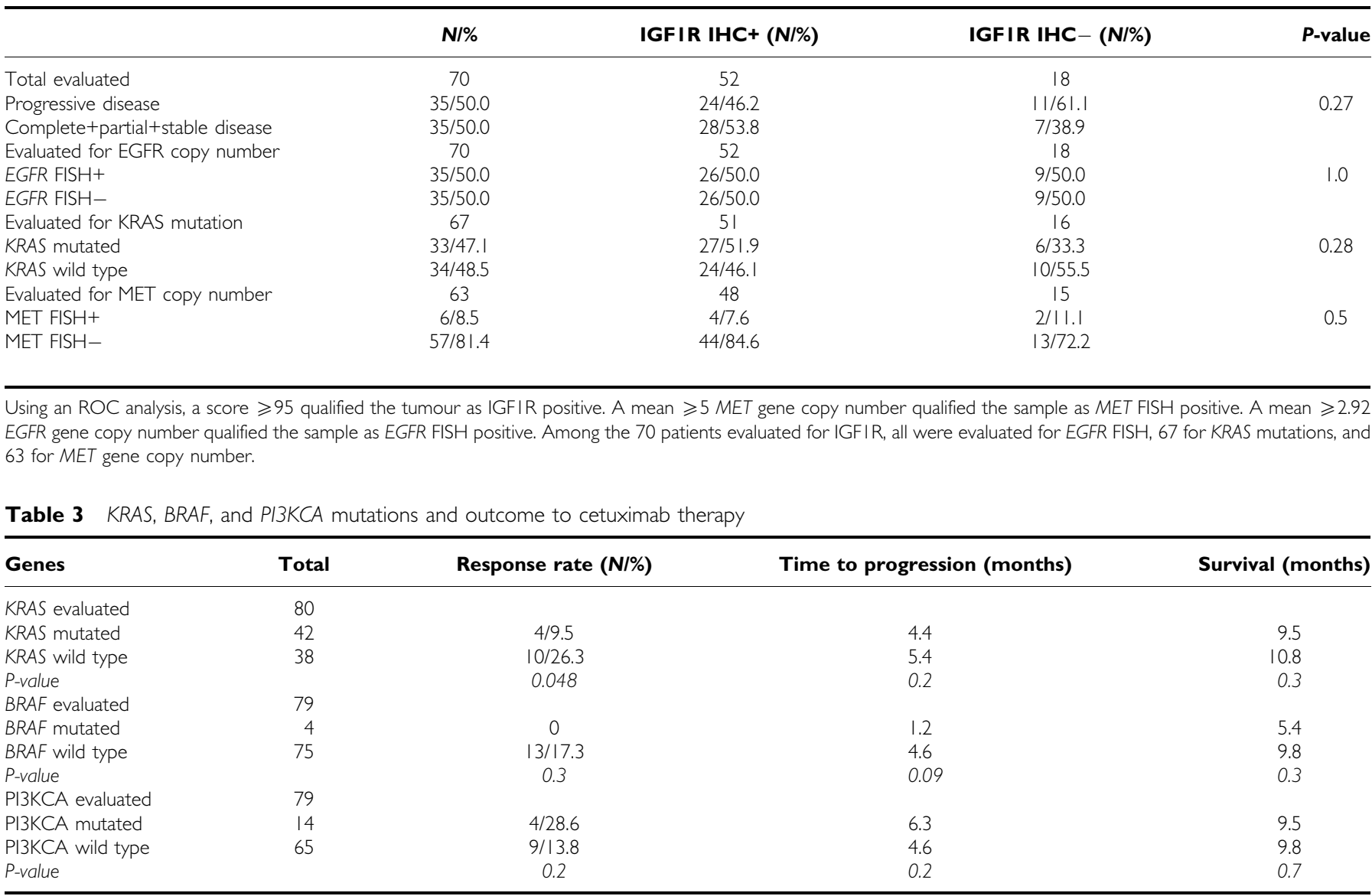

Table 4 Outcome of patients with KRAS or BRAF mutations stratified according to EGFR FISH status

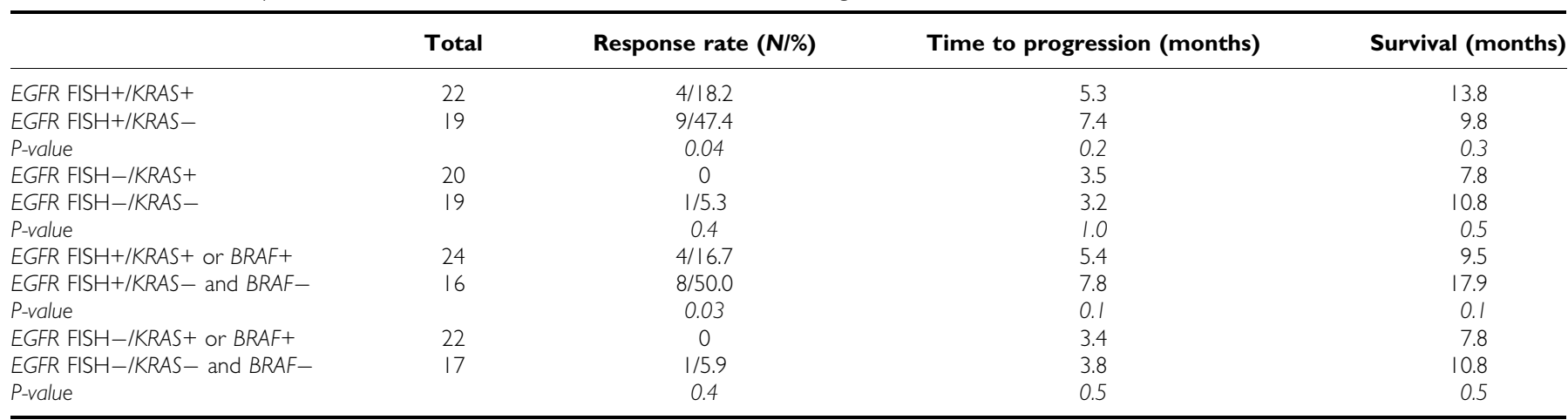

KRAS+: Presence of mutation; KRAS-: No mutation found. BRAF+: Presence of mutation; BRAF-: No mutation found.

OS resulted shorter than in BRAF wild-type individuals (TTP: 1.2 vs 5.4 months, $P=0.09$; OS: 5.4 vs 9.8 months, $P=0.3$ ).

A total of 79 patients were analysed for PI3KCA mutations. The gene was mutated in $14(17.7 \%)$ cases, with $\mathrm{H} 1047$ as the most frequent mutation type (seven cases, $8.8 \%$ ). No difference in response rate, TTP or OS was observed in patients harbouring a $P I 3 K C A$ mutation $v s$ wild type individuals. No $A K T$ mutation was identified among the 82 patients evaluated for this gene.

\section{Outcome according to mutation and EGFR FISH status}

To determine the relevance of KRAS or BRAF mutation in the presence or absence of the drug target $(E G F R)$, we analysed the outcome of patients according to EGFR FISH status (Table 4). KRAS mutations did not impact the outcome of EGFR FISHpatients. No difference in response rate (5.3 vs $0 \%, P=0.4)$, TTP (3.2 vs 3.5 months, $P=1)$ and $O S$ (10.8 vs 7.8 months, $P=0.5)$ was observed in EGFR FISH-IKRAS wild type vs EGFR FISH-/KRAS mutated. Conversely, EGFR FISH + /KRAS mutated had a significantly lower response rate $(18.2$ vs $47.7 \%, P=0.04)$ and shorter TTP (5.3 vs 7.4 months, $P=0.2$ ) than EGFR FISH + /KRAS wildtype patients. Interestingly, four EGFR FISH + patients with KRAS mutations (G12V in one case, G12D in another one, G13D in the remaining two cases) responded to cetuximab therapy. These patients had a mean EGFR gene copy number ranging from 3.03 to 4.03 . 
Similar results were obtained when the analysis was extended to patients with $K R A S$ or BRAF mutation. No difference in cetuximab sensitivity were observed in EGFR FISH - irrespective of KRAS and $B R A F$ status, while significantly lower response rate (16.7 vs $50.0 \%$, $P=0.037)$, shorter TTP (5.4 vs 7.8 months, $P=0.12$ ) and shorter OS (9.5 vs 17.9 months, $P=0.13$ ) was observed in EGFR FISH $+I$ KRAS or BRAF mutated $v s$ EGFR FISH + IKRAS or BRAF wild type.

\section{DISCUSSION}

In the present study, the first conducted in a mCRC population with known EGFR status, we showed that KRAS mutation is significantly associated with cetuximab failure in EGFR FISH + patients, even if it does not preclude response. Although preclinical data supported the negative impact of MET, IGF1R, and PI3KCA on cetuximab activity, in our study none of them demonstrated a clinical relevance as predictors for primary resistance, irrespective of the EGFR FISH result.

Previous studies demonstrated that KRAS mutations represent the most relevant mechanism responsible for anti-EGFR strategy failure (Lièvre et al, 2006, 2008; Di Fiore et al, 2007; KhambataFord et al, 2007; Amado et al, 2008; De Roock et al, 2008). Nevertheless, in CRC no data existed whether KRAS mutations drove cetuximab resistance in a patient population potentially sensitive to anti-EGFR agents, neither whether such events occurred in EGFR FISH + individuals. In the present study, we observed that the incidence of KRAS mutation was similar in EGFR FISH + and FISH - subgroups, indicating that these phenomena are not mutually exclusive. It is noteworthy that no difference in outcome was observed in the group of patients EGFR FISHirrespective of KRAS status, while the difference in response was significant only in EGFR FISH + . These results suggest that the drug maybe ineffective in absence of the target, while KRAS activation is able to drive drug resistance even if EGFR is present. Interestingly, in our population of KRAS mutated patients, four individuals responded to the therapy, and all were EGFR FISH positive. This finding raises the possibility that, in presence of an overexpressed target, occasionally tumour shrinkage could occur also in individuals harbouring the mutation.

$B R A F$ mutations were identified in $66 \%$ of melanomas, and in smaller percentage in other human cancers including colorectal (Davies et al, 2002). Our study confirmed that such mutation is not frequent in CRC and could represent an additional mechanism responsible for cetuximab failure. None of the patients carrying $B R A F$ mutation responded to the therapy, with a trend for shorter TTP and survival, differences not significant probably because of the small number of patients.

A recent study showed that colorectal cancer cell lines with activating PI3KCA mutations or with loss of PTEN expression were more resistant to cetuximab therapy than PI3KCA wild type/PTEN expressing cell lines (Jhawer et al, 2008). Importantly, simultaneous mutations of KRAS and PI3KCA conferred maximal resistance to cetuximab. In our study, combination of multiple mutation tests (KRAS or BRAF $\pm P I 3 K C A)$ did not provide additional information over a single mutation test (data not shown).

Previous studies have investigated MET in CRC with semiquantitative techniques such as immunoblotting or IHC (Di Renzo et al, 1995; Hiscox et al, 1997; Fujita and Sugano, 1997; Fukuura et al, 1998). Our study represents the first report in CRC assessing $M E T$ at the genomic level using FISH. We report here that MET amplification is a rare event in CRC, occurring in about $2 \%$ of cases. Only two patients had MET amplification and both responded to cetuximab therapy. Although the number of patients was too low for any conclusion, the level of $M E T$ gene gain observed in our study population was lower than reported in a previous study conducted on cell lines and patients with acquired resistance to anti EGFR agents (Engelman et al, 2007). Although obtained in tissues collected before starting cetuximab therapy, these findings suggest that only high level of $M E T$ gene gain could be responsible for resistance, levels probably occurring only under therapeutic pressure and rarely present in a general population of patients unexposed to anti-EGFR agents.

IGF1R is overexpressed in $50-90 \%$ of CRC (Weber et al, 2002; Koda et al, 2004), and preclinical studies suggested that this target could be responsible for resistance to anti-EGFR strategies (Chakravarti et al, 2002). In our study, IGF1R expression was not associated with cetuximab resistance, probably because the IGF1R pathway did not affect the antiproliferative activity of cetuximab, as recently observed in a lung cancer model (Morgillo et al, 2007). In the study conducted by Morgillo et al (2007) only the treatment with gefitinib, an EGFR-TKI, but not cetuximab, induced EGFR-IGF1R heterodimerisation and activation of IGF1R and its downstream signalling mediators, resulting in increased survivin expression in NSCLC cell lines with high levels of IGF1R expression. Interestingly, IGF1R-expressing patients had longer survival than IGF1R negative. A similar pattern has been observed in other malignancies such as non-small cell lung cancer or soft tissue sarcomas (Ahlén et al, 2005; Cappuzzo et al, 2006), whereas the opposite situation was found in other malignancies such as uveal melanoma and breast cancer (Turner et al, 1997; All-Ericsson et al, 2002). The significant association with survival is of particular relevance and merits further investigations, considering the number of strategies interfering with the IGF1R pathway under evaluation in solid cancers, including CRC. In our study, no patient had IGF1R gene amplification and the level of IGF1R gene gain was very low in the whole analysed population, suggesting that such event is not involved in primary resistance. Moreover, no association was found between IGF1R gene and protein expression, suggesting post-transcriptional events could also interfere with the gene function.

To conclude, the present study showed that presence of KRAS mutations represents the strongest predictor for cetuximab failure in EGFR FISH-positive CRC patients. The rarity of MET and IGF1R gene amplification suggest that such biological events play a limited role in primary resistance to anti-EGFR agents. The impact of $B R A F$ mutation on cetuximab resistance as well as the potential prognostic implications of IGF1R expression requires further investigation.

\section{ACKNOWLEDGEMENTS}

We are indebted to the Tissue Procurement and Cytogenetics Cores of the University of Colorado Cancer Center and the Dana Farber Cancer Institute for technical assistance. Supported by the Umbria Association Against Cancer (GF).

\section{REFERENCES}

Ahlén J, Wejde J, Brosjö O, von Rosen A, Weng WH, Girnita L, Larsson O, Larsson C (2005) Insulin-like growth factor type 1 receptor expression correlates to good prognosis in highly malignant soft tissue sarcoma. Clin Cancer Res 11: 206-216
All-Ericsson C, Girnita L, Seregard S, Bartolazzi A, Jager MJ, Larsson O (2002) Insulin-like growth factor-1 receptor in uveal melanoma: a predictor for metastatic disease and a potential therapeutic target. Invest Ophthalmol Vis Sci 43: 1-8 
Amado RG, Wolf M, Peeters M, Van Cutsem E, Siena S, Freeman DJ, Juan T, Sikorski R, Suggs S, Radinsky R, Patterson SD, Chang DD (2008) Wild-type KRAS is required for panitumumab efficacy in patients with metastatic colorectal cancer. J Clin Oncol 26: 1626-1634

Bamford S, Dawson E, Forbes S, Clements J, Pettett R, Dogan A, Flanagan A, Teague J, Futreal PA, Stratton MR, Wooster R (2004) The COSMIC (catalogue of somatic mutations in cancer) database and website. $\mathrm{Br}$ J Cancer 91: 355-358

Baserga R, Hongo A, Rubini M, Prisco M, Valentinis B (1997) The IGF-I receptor in cell growth, transformation and apoptosis. Biochim Biophys Acta 1332: F105-F126

Blakesley VA, Stannard BS, Kalebic T, Helman LJ, LeRoith D (1997) Role of the IGF-I receptor in mutagenesis and tumor promotion. J Endocrinol 152: $339-344$

Cai T, Moskowitz CS (2004) Semi-parametric estimation of the binomial ROC curve for a continuous diagnostic test. Biostatistics 5: 573-586

Cappuzzo F, Finocchiaro G, Rossi E, Jänne PA, Carnaghi C, Calandri C, Bencardino K, Ligorio C, Ciardiello F, Pressiani T, Destro A, Roncalli M, Crino L, Franklin WA, Santoro A, Varella-Garcia M (2008) EGFR FISH assay predicts for response to cetuximab in chemotherapy refractory colorectal cancer patients. Ann Oncol 19: 717-723

Cappuzzo F, Toschi L, Tallini G, Ceresoli GL, Domenichini I, Bartolini S, Finocchiaro G, Magrini E, Metro G, Cancellieri A, Trisolini R, Crino L, Bunn Jr PA, Santoro A, Franklin WA, Varella-Garcia M, Hirsch FR (2006) Insulin-like growth factor receptor 1 (IGFR-1) is significantly associated with longer survival in non-small-cell lung cancer patients treated with gefitinib. Ann Oncol 17: 1120-1127

Chakravarti A, Loeffler JS, Dyson NJ (2002) Insulin-like growth factor receptor I mediates resistance to anti-epidermal growth factor receptor therapy in primary human glioblastoma cells through continued activation of phosphoinositide 3-kinase signaling. Cancer Res 62: 200-207

Chung KY, Shia J, Kemeny NE, Shah M, Schwartz GK, Tse A, Hamilton A, Pan D, Schrag D, Schwartz L, Klimstra DS, Fridman D, Kelsen DP, Saltz LB (2005) Cetuximab shows activity in colorectal cancer patients with tumors that do not express the epidermal growth factor receptor by immunohistochemistry. J Clin Oncol 23: 1803-1810

Davies H, Bignell GR, Cox C, Stephens P, Edkins S, Clegg S, Teague J, Woffendin H, Garnett MJ, Bottomley W, Davis N, Dicks E, Ewing R, Floyd Y, Gray K, Hall S, Hawes R, Hughes J, Kosmidou V, Menzies A, Mould C, Parker A, Stevens C, Watt S, Hooper S, Wilson R, Jayatilake H, Gusterson BA, Cooper C, Shipley J, Hargrave D, Pritchard-Jones K, Maitland N, Chenevix-Trench G, Riggins GJ, Bigner DD, Palmieri G, Cossu A, Flanagan A, Nicholson A, Ho JW, Leung SY, Yuen ST, Weber BL, Seigler HF, Darrow TL, Paterson H, Marais R, Marshall CJ, Wooster R, Stratton MR, Futreal PA (2002) Mutations of the BRAF gene in human cancer. Nature 417: 949-954

De Gramont A, Figer A, Seymour M, Homerin M, Hmissi A, Cassidy J, Boni C, Cortes-Funes H, Cervantes A, Freyer G, Papamichael D, Le Bail N, Louvet C, Hendler D, de Braud F, Wilson C, Morvan F, Bonetti A (2000) Leucovorin and fluorouracil with or without oxaliplatin as first-line treatment in advanced colorectal cancer. J Clin Oncol 18: 2938-2947

De Roock W, Piessevaux H, De Schutter J, Janssens M, De Hertogh G, Personeni N, Biesmans B, Van Laethem JL, Peeters M, Humblet Y, Van Cutsem E, Tejpar S (2008) KRAS wild-type state predicts survival and is associated to early radiological response in metastatic colorectal cancer treated with cetuximab. Ann Oncol 19: 508-515

Di Fiore F, Blanchard F, Charbonnier F, Le Pessot F, Lamy A, Galais MP, Bastit L, Killian A, Sesboüé R, Tuech JJ, Queuniet AM, Paillot B, Sabourin JC, Michot F, Michel P, Frebourg T (2007) Clinical relevance of KRAS mutation detection in metastatic colorectal cancer treated by Cetuximab plus chemotherapy. Br J Cancer 96: 1166-1169

Di Renzo MF, Olivero M, Giacomini A, Porte H, Chastre E, Mirossay L, Nordlinger B, Bretti S, Bottardi S, Giordano S (1995) Overexpression and amplification of the met/HGF receptor gene during the progression of colorectal cancer. Clin Cancer Res 1: 147-154

Douillard JY, Cunningham D, Roth AD, Navarro M, James RD, Karasek P, Jandik P, Iveson T, Carmichael J, Alakl M, Gruia G, Awad L, Rougier P (2000) Irinotecan combined with fluorouracil compared with fluorouracil alone as first-line treatment for metastatic colorectal cancer: multicentre randomised trial. Lancet 355: 1041-1047

Dufourny B, Alblas J, van Teeffelen HA, van Schaik FM, van der Burg B, Steenbergh PH, Sussenbach JS (1997) Mitogenic signaling of insulin-like growth factor I in MCF-7 human breast cancer cells requires phosphatidylinositol 3-kinase and is independent of mitogen-activated protein kinase. J Biol Chem 272: $31163-31171$
Engelman JA, Zejnullahu K, Mitsudomi T, Song Y, Hyland C, Park JO, Lindeman N, Gale CM, Zhao X, Christensen J, Kosaka T, Holmes AJ, Rogers AM, Cappuzzo F, Mok T, Lee C, Johnson BE, Cantley LC, Jänne PA (2007) MET amplification leads to gefitinib resistance in lung cancer by activating ERBB3 signaling. Science 316: 1039-1043

Fujita S, Sugano K (1997) Expression of c-met proto-oncogene in primary colorectal cancer and liver metastases. Jpn J Clin Oncol 27: 378-383

Fukuura T, Miki C, Inoue T, Matsumoto K, Suzuki H (1998) Serum hepatocyte growth factor as an index of disease status of patients with colorectal carcinoma. Br J Cancer 78: 454-459

Graziani A, Gramaglia D, Cantley LC, Comoglio PM (1991) The tyrosinephosphorylated hepatocyte growth factor/scatter factor receptor associates with phosphatidylinositol 3-kinase. J Biol Chem 266: 22087-22090

Hakam A, Yeatman TJ, Lu L, Mora L, Marcet G, Nicosia SV, Karl RC, Coppola D (1999) Expression of insulin-like growth factor-1 receptor in human colorectal cancer. Hum Pathol 30: 1128-1133

Halaban R, Rubin JS, Funasaka Y, Cobb M, Boulton T, Faletto D, Rosen E, Chan A, Yoko K, White W, Cook C, Moellmann G (1992) Met and hepatocyte growth factor/scatter factor signal transduction in normal melanocytes and melanoma cells. Oncogene 7: 2195-2206

Hiscox SE, Hallett MB, Puntis MC, Nakamura T, Jiang WG (1997) Expression of the HGF/SF receptor, c-met, and its ligand in human colorectal cancers. Cancer Invest 15: 513-521

Jänne PA, Borras AM, Kuang Y, Rogers AM, Joshi VA, Liyanage H, Lindeman N, Lee JC, Halmos B, Maher EA, Distel RJ, Meyerson M, Johnson BE (2006) A rapid and sensitive enzymatic method for epidermal growth factor receptor mutation screening. Clin Cancer Res 12: 751-758

Jemal A, Siegel R, Ward E, Murray T, Xu J, Thun MJ (2007) Cancer statistics, 2007. CA Cancer J Clin 57: 43-66

Jhawer M, Goel S, Wilson AJ, Montaqna C, Ling YH, Byun DS, Nasser S, Arango D, Shin J, Klampfer L, Auquenlicht LH, Soler RP, Mariadason JM (2008) P1K3CA mutation/PTEN expression status predicts response of colon cancer cells to the epidermal growth factor receptor inhibitor cetuximab. Cancer Res 15: 1953-1961

Jiang W, Hiscox S, Matsumoto K, Nakamura T (1999) Hepatocyte growth factor/scatter factor, its molecular, cellular and clinical implications in cancer. Crit Rev Oncol-Hematol 29: 209-248

Jones JI, Clemmons DR (1995) Insulin-like growth factors and their binding proteins: biological actions. Endocr Rev 16: 3-34

Jonker DJ, O'Callaghan CJ, Karapetis CS, Zalcberg JR, Tu D, Au HJ, Berry SR, Krahn M, Price T, Simes RJ, Tebbutt NC, van Hazel G, Wierzbicki R, Langer C, Moore MJ (2007) Cetuximab for the treatment of colorectal cancer. N Engl J Med 357: 2040 - 2048

Kaplan EL, Meier P (1985) Nonparametric estimation from incomplete observations. J Am Stat Assoc 53: 457-481

Khambata-Ford S, Garrett CR, Meropol NJ, Basik M, Harbison CT, Wu S, Wong TW, Huang X, Takimoto CH, Godwin AK, Tan BR, Krishnamurthi SS, Burris III HA, Poplin EA, Hidalgo M, Baselga J, Clark EA, Mauro DJ (2007) Expression of epiregulin and amphiregulin and K-ras mutation status predict disease control in metastatic colorectal cancer patients treated with cetuximab. J Clin Oncol 25: 3230-3237

Khandwala HM, McCutcheon IE, Flyvbjerg A, Friend KE (2000) The effects of insulin-like growth factors on tumorigenesis and neoplastic growth. Endocr Rev 21: 215-244

Koda M, Reszec J, Sulkowska M, Kanczuga-Koda L, Sulkowski S (2004) Expression of the insulin-like growth factor-I receptor and proapoptotic Bax and Bak proteins in human colorectal cancer. Ann N Y Acad Sci 1030: $377-383$

LeRoith D, Werner H, Beitner-Johnson D, Roberts Jr CT (1995) Molecular and cellular aspects of the insulin-like growth factor I receptor. Endocr Rev 16: $143-163$

Lièvre A, Bachet JB, Boige V, Cayre A, Le Corre D, Buc E, Ychou M, Bouché O, Landi B, Louvet C, André T, Bibeau F, Diebold MD, Rougier P, Ducreux M, Tomasic G, Emile JF, Penault-Llorca F, Laurent-Puig P (2008) KRAS mutations as an independent prognostic factor in patients with advanced colorectal cancer treated with cetuximab. J Clin Oncol 26: $374-379$

Lièvre A, Bachet JB, Le Corre D, Boige V, Landi B, Emile JF, Côté JF, Tomasic G, Penna C, Ducreux M, Rougier P, Penault-Llorca F, Laurent-Puig P (2006) KRAS mutation status is predictive of response to cetuximab therapy in colorectal cancer. Cancer Res 66: 3992-3995

Long IS, Han K, Li M, Shirasawa S, Sasazuki T, Johnston M, Tsao MS (2003) Met receptor overexpression and oncogenic Ki-ras mutation cooperate to enhance tumorigenicity of colon cancer cells in vivo. Mol Cancer Res 1: $393-401$ 
Morgillo F, Kim WY, Kim ES, Ciardiello F, Hong WK, Lee HY (2007) Implication of the insulin-like growth factor-IR pathway in the resistance of non-small cell lung cancer cells to treatment with gefitinib. Clin Cancer Res 13: 2795-2803

Moroni M, Veronese S, Benvenuti S, Marrapese G, Sartore-Bianchi A, Di Nicolantonio F, Gambacorta M, Siena S, Bardelli A (2005) Gene copy number for epidermal growth factor receptor (EGFR) and clinical response to antiEGFR treatment in colorectal cancer: a cohort study. Lancet Oncol 6: 279-286

Ponzetto C, Bardelli A, Maina F, Longati P, Panayotou G, Dhand R, Waterfield MD, Comoglio PM (1993) A novel recognition motif for phosphatidylinositol 3-kinase binding mediates its association with the hepatocyte growth factor/scatter factor receptor. Mol Cell Biol 13: 4600-4608

Rodriguez-Viciana P, Warne PH, Dhand R, Vanhaesebroeck B, Gout I, Fry MJ, Waterfield MD, Downward J (1994) Phosphatidylinositol-3-OH kinase as a direct target of Ras. Nature 370: 527-532

Sartore-Bianchi A, Moroni M, Veronese S, Carnaghi C, Bajetta E, Luppi G, Sobrero A, Barone C, Cascinu S, Colucci G, Cortesi E, Nichelatti M,
Gambacorta M, Siena S (2007) Epidermal growth factor receptor gene copy number and clinical outcome of metastatic colorectal cancer treated with panitumumab. J Clin Oncol 25: 3238-3245

Therasse P, Arbuck SG, Eisenhauer EA, Wanders J, Kaplan RS, Rubinstein L, Verweij J, Van Glabbeke M, van Oosterom AT, Christian MC, Gwyther SG (2000) New guidelines to evaluate the response to treatment in solid tumors. European Organization for Research and Treatment of Cancer, National Cancer Institute of the United States, National Cancer Institute of Canada. J Natl Cancer Inst 92: $205-216$

Turner BC, Haffty BG, Narayanan L, Yuan J, Havre PA, Gumbs AA, Kaplan L, Burgaud JL, Carter D, Baserga R, Glazer PM (1997) Insulin-like growth factor-I receptor overexpression mediates cellular radioresistance and local breast cancer recurrence after lumpectomy and radiation. Cancer Res 57: 3079-3083

Weber MM, Fottner C, Liu SB, Jung MC, Engelhardt D, Baretton GB (2002) Overexpression of the insulin-like growth factor I receptor in human colon carcinomas. Cancer 95: 2086-2095 